\title{
Ascertaining Requisite Metacognitive Elements of Input through the Exploration of Language Learners' Cognitive Characteristics
}

\author{
W.M.P.Y.B. Rathnayake ${ }^{1^{*}}$ \\ ${ }^{1}$ Department of Languages, University of Moratuwa, Moratuwa, Sri Lanka \\ * prasannar@uom.1k
}

\begin{abstract}
Cognitive theory emphasizes language learning as a conscious and reasoned thinking process involved in the use of deliberate learning strategies. Exploration of the cognitive characteristics of learner provides benchmarks to define metacognitive components required, thus easing the planning of input in an English as Second Language (ESL) classroom. In view of espousing deliberate learning strategies in input, this study identifies due metacognitive components for ESL input upon diagnosing the cognitive characteristics of learners. The research questions include, what cognitive strategies learners do possess, what correlative natures are visible in cognitive strategies in learner possession, and which metacognitive components are to be espoused in ESL input. Proposing a questionnaire aligned with the taxonomy of metacognition, its viability for investigating prevalent learner cognitive/metacognitive characteristics is tested. The survey among 110 engineering undergraduates provides qualitative data about learner traits reflective of metacognitive behaviors. Responses were collected in a Likert scale corresponding to a defined metacognitive scale, and the cumulative means of the responses against each aspect of metacognition are stratified in a radar chart forming the learner portfolio of metacognitive strategy in use. Correlative tests are executed among prevailing cognitive traits seeking evidences for the unified nature of learner metacognitive behaviours. Results proved the prevalence of metacognitive strategies through evidences of learners' metacognitive feelings and judgements besides a proven correlation among planning, monitoring and control behaviors towards enabling metacognitive feelings/judgements. Precision of the diagnostic tool and the cohesive visibility of the metacognitive portfolio remain significant results with opportunity for further research.
\end{abstract}

Key words: Cognition, ESL Input, Learner characteristics, Metacognition, Portfolio

\section{Introduction}

Saville-Toike (2012) makes the distinction between mother tongue (L1) acquisition and Second Language (L2) learning in the following context. L1 is the mother tongue acquired during early childhood (mostly before 3 years old). It is acquired in the process of growing up with the people who speak the same language. If an individual or a group of them learns another language ensuing L1, it is the second language [Saville-Toike, 2012].

Over the centuries to the date, learning or acquiring language has been a stimulus for many researchers and they have seen the issue in three distinct perspectives. Behaviorists perceive this phenomena in the stimulusresponse base as "Say what I say" to be the approach for language acquisition. Innatist observation of the language acquisition is: "It's all in your mind" as they base Language acquisition Devise (LAD) and Universal Grammar (UG) in their approach. Interactionists consider language acquisition as a result of "A little help from my friends" as they reside in the paramount importance of interaction [Lightbrown \& Spada, 2006]. In a review of the three perspectives, Mohamad \& Rashid (2018) admit to the fact that none of these three theories alone can suffice to help learning or acquisition but all three in combination [Mohamad \& Rashid, 2018].

However, first language acquisition is seen implicit as it is extracted from experience rather than explicit rule teaching. Yet, learning L2 needs explicit learn- ing. Krashen (1982) makes the distinction between implicit acquisition and explicit learning of L2 in his input hypothesis. In Krashen's theory, Second Language Acquisition (SLA) is identical to L1 acquisition that comes naturally as a result of implicit processes occurring while the learner is receiving comprehensible input [Krashen, 1982].

The distinction is that when the cognitive system of a learner whose mother tongue or first language being something else than the languages/he intends to learn/acquire, there can possibly be coinciding and/or contradicting stimuli between the cognitive system configured for the first language which is in the learner's possession. Thus the approaches to second language teaching should locate their philosophies on the prevalent cognizance of intended learners on their own cognitive system. Emphasizing this view for future research Doughty \& Long (2003) claim that in order to properly address the SLA issues, studies of implicit and explicit language knowledge inclusive of: SLA, applied linguistics, cognition, consciousness, learning, education, and brain must proceed in consort within the broader inquiries of cognitive science and cognitive neuroscience [Doughty \& Long, 2003].

In order to provide a comprehensible input as prescribed by Krashen (1982) to foster SLA, while obeying to the suggestion to combine all three theories (behaviorism, innatism and interactionism) of language acquisition, the present study endeavors to materialize a cog- 
Table 1: Tabulated taxonomy items of metacognition with questionnaire items

\begin{tabular}{|c|c|c|c|c|}
\hline & Category & Super category & Subcategories & $\begin{array}{l}\text { Questionnaire item vs } \\
\text { traits under diagnosis }\end{array}$ \\
\hline \multirow{13}{*}{ 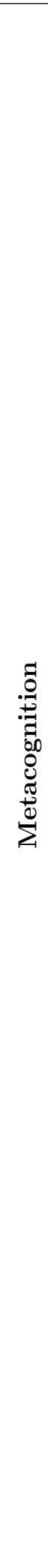 } & \multirow{9}{*}{ 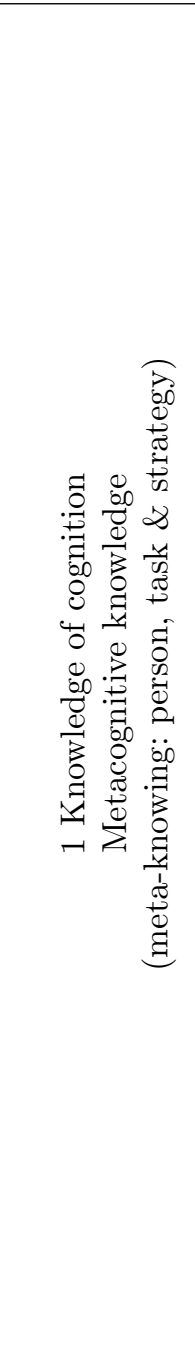 } & \multirow{3}{*}{$\begin{array}{l}1.1 \\
\text { Declarative metacogni- } \\
\text { tive knowledge } \\
\text { (knowing the self) }\end{array}$} & 1.1.1 Knowledge of self & $\begin{array}{l}1 \text { My experience in } \\
\text { university with English }\end{array}$ \\
\hline & & & $\begin{array}{l}\text { 1.1.2 Knowledge of task } \\
\& \text { context }\end{array}$ & $\begin{array}{l}2.1 \text { How do I prepare for } \\
\text { my learning? What is the } \\
\text { most difficult area? }\end{array}$ \\
\hline & & & $\begin{array}{l}\text { 1.1.3 Knowledge of strat- } \\
\text { egy }\end{array}$ & $\begin{array}{l}2.2 \text { How do I choose } \\
\text { and decide my learning } \\
\text { needs? }\end{array}$ \\
\hline & & \multirow{3}{*}{$\begin{array}{l}1.2 \\
\text { Procedural metacogni- } \\
\text { tive knowledge } \\
\text { (Knowing How) }\end{array}$} & $\begin{array}{l}\text { 1.2.1 Knowledge of self \& } \\
\text { others }\end{array}$ & $\begin{array}{l}2.3 \text { Do I decide what I } \\
\text { need to learn? }\end{array}$ \\
\hline & & & $\begin{array}{l}\text { 1.2.2 Knowledge of task } \\
\text { \& context }\end{array}$ & $\begin{array}{l}\text { 3.1 Am I always willing } \\
\text { and ready to do learning? }\end{array}$ \\
\hline & & & $\begin{array}{l}\text { 1.2.3 Knowledge of strat- } \\
\text { egy }\end{array}$ & $\begin{array}{l}2.4 \text { I usually plan \& } \\
\text { list out what I should do } \\
\text { to achieve my language } \\
\text { goals. }\end{array}$ \\
\hline & & \multirow{3}{*}{$\begin{array}{l}1.3 \\
\text { Conditional metacog- } \\
\text { nitive knowledge } \\
\text { (knowing when, where, } \\
\text { why) }\end{array}$} & $\begin{array}{l}\text { 1.3.1 Knowledge of self \& } \\
\text { others }\end{array}$ & $\begin{array}{l}4 \text { How do I interact with } \\
\text { my colleagues in my mis- } \\
\text { sion for learning English } \\
\text { language? }\end{array}$ \\
\hline & & & $\begin{array}{l}\text { 1.3.2 Knowledge of task } \\
\& \text { context }\end{array}$ & $\begin{array}{l}5 \text { How do I accept/relate } \\
\text { the results of my interac- } \\
\text { tion with my colleagues? }\end{array}$ \\
\hline & & & $\begin{array}{l}\text { 1.3.3 Knowledge of strat- } \\
\text { egy }\end{array}$ & $\begin{array}{l}2.5 \text { Can I distinguish } \\
\text { strategies to achieve my } \\
\text { goals of language learn- } \\
\text { ing? }\end{array}$ \\
\hline & \multirow{4}{*}{ 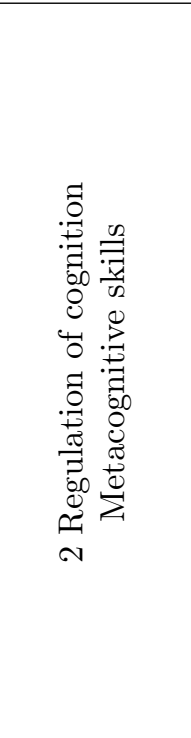 } & \multirow{4}{*}{$\begin{array}{l}2.1 . \\
\text { Regulation of cog- } \\
\text { nition \& Executive } \\
\text { Functioning }\end{array}$} & $\begin{array}{l}2.1 .1 \text { Monitoring \& con- } \\
\text { trol }\end{array}$ & $\begin{array}{l}3.2 \text { I make a 'to do } \\
\text { list' including the strate- } \\
\text { gies I'm using for each } \\
\text { sub task. }\end{array}$ \\
\hline & & & 2.1.2 Self-regulation & $\begin{array}{l}3.3 \text { Do I evaluate my } \\
\text { improvement towards } \\
\text { achieving my goals? }\end{array}$ \\
\hline & & & $\begin{array}{l}\text { 2.2.1 Metacognitive Feel- } \\
\text { ings }\end{array}$ & $\begin{array}{l}6 \text { What sense of cognition } \\
\text { do I have on my mission } \\
\text { for learning English lan- } \\
\text { guage? }\end{array}$ \\
\hline & & & $\begin{array}{l}2.2 .2 \quad \text { Metacognitive } \\
\text { Judgments }\end{array}$ & $\begin{array}{l}3.4 \text { Do I usually evalu- } \\
\text { ate my strategies and } \\
\text { amend/correct them } \\
\text { towards achieving my } \\
\text { goals? }\end{array}$ \\
\hline
\end{tabular}

nitive diagnostic tool capable of plotting existing cognitive characteristics of the learners.
The diagnosis of learner cognitive characteristics in advance to planning the cognitive and metacognitive ele- 
Table 2: An example of Likert options corresponding to the metacognitive scale.

\begin{tabular}{lcl}
\hline Metacognitive Scale & Value & Example: Q $\mathbf{3 . 4}$ \\
\hline Utter-Negative & & I evaluate my improvement towards achieving my goals. \\
Negative & -2 & No I never do evaluate my improvement. \\
Neutral & -1 & I don't try evaluating my improvement \\
Developing & 0 & I don't know whether I do assess or not \\
Positive & +1 & Yes, I do assess my improvement \\
\hline
\end{tabular}

ments of in the English as Second Language (ESL) input is considered a pivotal step in input planning. Attempts of diagnosing the prevalent cognizance of learners in advance of the exposure to ESL learning experience are of much limit. This is perhaps a consequence of ESL practitioners' adherence to learning outcomes as the central concern in ESL input planning which naturally forces them to overlook the significance of diagnosing the prevailing status of cognition of the learner. The objective of this study is to deliberate the need of diagnosing the significance of learner cognition prior to planning the input of second language teaching and to propose a tool viable for diagnosing such learner traits relevant to ESL context.

The area of investigation of the present study should not be misconceived with diagnostic language assessments (DLA) which refers to the processes of identifying test-takers' or learners' weaknesses, as well as their strengths, in a targeted domain of linguistic and communicative competence and providing specific diagnostic feedback and guidance for remedial learning.

The aim of the present study is to locate a diagnostic test capable of discovering the existing cognitive traits of the learners thus capacitating the ESL input planner to discern due metacognitive elements in ESL input to nurture learners' cognitive status towards metacognitive learning. In this view the study concerns two concepts namely, cognition and metacognition. Metacognition in definition is about cognition of oneself on his own cognitive phenomena. The higher order construct is metacognition and the foundation in which it is constructed is cognition.

Langford (1986) describes cognition as 'constant flow of information'. The American Heritage Dictionary of the English Language (2000) defines cognition as "the mental process of knowing, including aspects such as awareness, perception, reasoning, and judgment". Metacognition in contrast is the consciousness of one's own abilities, for example, a child understands that he/she is able to read. The distinction is that by making use of metacognition people can regulate their learning processes. It refers to how the task is understood and how solutions are evaluated and monitored.
In other words, the domain of metacognition includes knowledge and awareness of process of knowing and the monitoring and control of such knowledge and processes [Flavell, 1976, Flavell et al., 1993, Schraw, 2001].

Learners' cognizance of their own cognition has been a stimuli for research as early as 1949 as Witkin (1949, 1978) identified them as learner characteristics. Witkin considers learner characteristics as characteristic modes of functioning of highly consistent and pervasive nature in perceptual and intellectual activities. Learner characteristics are seen as traits of the possession of learners which are distinguished from learners' states that can be influenced easily [Witkin, 1949, Witkin, 1978].

Learner characteristics evaluate a wide spectrum of learner traits of personal, academic, social and cognitive dimensions from which the present study falls within cognitive dimension of the learner characteristics. The cognitive dimension of the learner characteristics considers how the learner perceives, remembers, thinks, solves problems, organizes and represent information in brain. Guilford in 1967 considers cognitive learner characteristics as intellectual abilities which perceives along three dimensions: operations, content and products. As Guilford's definition operation includes: cognition, memory, divergent production, convergent production, and evaluation while content being visual, auditory, symbolic, semantic, and behavioral. The production in his organizing includes units, classes, relations, systems, transformations, and implications [Guilford, 1967].

The amalgamation of specific instructional approaches for specific learner characteristics began in 1970s with Cronbach and Snow's model (1977) of Aptitude Treatment Interactions which presumes that optimal learning is the result of the instruction being perfectly matched to the learner's aptitudes. Their model held the fact that certain instructional strategies will be more or less effective for different individuals depending upon the individual's specific abilities such as aptitude [Cronbach \& Snow, 1977].

Among many approaches to merge learner characteristics, especially the cognitive characteristics in instructional contexts, the approaches to instruct metacognition and apprenticeship to metacognitive phenom- 
Table 3: Correlation between Planning and the ability for distinguishing strategies.

\begin{tabular}{llcc}
\hline Independent variable & Dependent variable & P-correlation & Significance (2-tailed) \\
\hline $\begin{array}{l}\text { I usually plan myself and } \\
\text { list out what I should do to }\end{array}$ & $\begin{array}{l}\text { I can distinguish strategies } \\
\text { to achieve my goals of lan- } \\
\text { achieve my language goals }\end{array}$ & $0.392^{* *}$ & 0.000 \\
\hline
\end{tabular}

$$
\mathbf{N}=110
$$

Correlation is significant at the 0.01 level (2-tailed).

ena remain crucial as such has influenced the pedagogy immensely. Bransford, Brown, \& Cocking, (2000) evaluate "how people learn: brain, mind, experience, and school" and admit the fact that "a metacognitive approach to instruction can help students learn to take control of their own learning by defining learning goals and monitoring their progress in achieving them" [Bransford et al., 2000]. Further researches by them together with Pintrich (2002), Pintrich \& De Groot (1990) admit that the metacognitive skills may improve the academic performance when such strategies are explicitly taught within disciplines thus making students able to transfer such strategies from one contexts to another [Pintrich, 2002, Pintrich \& De Groot, 1990].

Rubin (1975) distinguishes the direct relationship between good language learners and their learning strategies. Such learning strategies include conscious thoughts and actions that learner takes for achieving a learning goal thus convincing us the affiliation between cognitive learner characteristics and strategies [Rubin, 1975]. Chamot (2004) claims that strategic learners have metacognitive knowledge about their own thinking and learning approaches, a good understanding of what a task entails, and the ability to orchestrate the strategies that best meet both the task demands and their own learning strengths [Chamot, 2004].

The empirical proofs of Neitfeld \& Schraw, Thiede, Anderson \& Therrriault in 2003 on the instructional ability of the metacognitive skills lead the metacognitive research field in to the classroom. Following this trend many researchers agree on the ability to instruct knowledge of cognition and the regulation of cognition and thus they prescribe explicit teaching of them in classroom [Cross \& Paris, 1988, Pintrich, 2002, Schraw, 1998, Schraw et al., 2006, Tanner, 2012].

Chamot (1995) quotes Krashen's hypothesis that "second language learning occurred through implicit, unconscious processes activated by appropriate input" thus unveiling the need for such strategy to be a component of the L2 input [Chamot, 1995]. As a result of the direction suggested by the input hypothesis of Krashen, SLA studies shifted to look at language learning from the cognitive learning theory perspective. Among the many strategies in concern relevant to language learners, metacognitive strategy plays a vital role than any other. As Anderson (2003) observes, language acquisi- tion proceeds at a faster rate when learners become capable of knowing how their own learning process occurs and regulating their own learning over the use of strategies [Anderson, 2003]. Rubin (1987) admits that metacognitive knowledge is crucial for learners selecting and activating strategies [Rubin, 1987] and Goh (2008) states that the teachers strive for developing students' own metacognition and commitment to teach them how to use effective strategies for the kinds of tasks they need to accomplish in the process of language learning as vital elements [Goh, 2008].

Oxford (2003) advocates that metacognitive strategies include: identifying one's own learning style preferences and needs, planning for an L2 task, gathering and organizing materials, arranging a study space and a schedule, monitoring mistakes, and evaluating task success, and evaluating the success of any type of learning strategy which are employed for managing the learning process overall. This detailed cataloguing (of metacognitive strategies) helps ESL planner to spot and espouse them in input thus stimulating them in interaction.

Having reviewed via all these literature, it came clear that the apprenticeship to metacognitive skills \& strategies through ESL input is of promising nature for its constructive impact on language acquisition. Pressley (2000) prescribes that if metacognition is obviously of particular relevance to poor students. The three principles from the literature for successful cognitive and metacognitive instruction includes: embedding metacognitive instruction in the content ensuring connectivity, informing the usefulness of metacognitive activities urging an extra effort, prolonged training to guarantee the application of metacognitive activity [Pressley, 2000].

Having spotted the significance of incorporating metacognitive skills in ESL input obliging to the prescriptions of Pressley (2000), the present study considers the vitality of diagnosing existing cognitive characteristics of the learner as such can assist as the benchmarks to guide the incorporation of due cognitive and metacognitive skills.

The present study having aimed at clearing the fuzzy doubts in delineating a starting point for ESL input planners to espouse cognitive apprenticeship and metacognitive elements in input, considers exploration of the following issues. 
a. What metacognitive strategies are students already aware of in learning ESL?

b. What correlative natures are visible in cognitive strategies in learner possession?

c. Which metacognitive domains should the learners require in prolonged apprenticeship?

\section{Methods}

The central objective of the survey remains diagnosing the existing cognitive characteristics of the learners thus enabling the instructional designer to decide on a starting point to espouse strategies to uplift cognitive and metacognitive apprenticeship of learners. The study entails a secondary objective to investigate the aspects of metacognition possessed by the learners and possible correlative natures of the constituents of metacognition. Being considerate of what metacognitive strategies are students aware of in learning ESL, which strategies do they perceive as relevant for their studies, and which cognitive/metacognitive domains should the learners require prolonged apprenticeship the study proposes a questionnaire aligned with taxonomy of metacognition by Tarricone (2011) which provides a theoretical framework of the cognitive traits possessed by learners.

\section{Development of the Research Tool, Sam- pling \& Validating the Tool}

In search of an optimum tool for the investigation of learner cognitive characteristics, the researcher worked out an agenda on observing the learners in his ESL classroom of 35 students. The key assumption of the observation plan was that the learner behavior is the consequence resulted owing to the cognitive characteristics and experience of the learner in language classroom. Five distinct aspects/areas of the learners' behavior have been traced in these observations. They include: learner perceptions about the experience in the English language classroom, learner preparations for the language learning task, execution the mission of learning, learner interactions with peers, and the way in which learners accept/relate the results of their interaction. Having framed such aspects/areas of learner behaviours in the category, sub-category and super-category items of the taxonomy of metacognition, the researcher formulated queries for each of the items. The tabulated taxonomy items of metacognition with questionnaire items given in Table 1 illustrates the alignment of questionnaire with the taxonomy.

Such questions were tested in a structured key informant interview among 14 students selected on the following basis.

Considering the observation on individual learners and their socio, demographic and language proficiency aspects, three groups of students were selected for key informant interviews. Four students each from among the learners who possessed the greatest and the lowest confidence over English medium were considered for group $\mathrm{A}$ and $\mathrm{B}$ consequently thus aligning with purposive sampling. Group $\mathrm{C}$ which had six students has been randomly selected from the class avoiding the members of group A and B categories. The learners of B and $\mathrm{C}$ groups had difficulties in understanding questions raised, thus a translation of the question is offered for them and they were allowed to answer in their mother tongue (Sinhalese). These 16 learners were interviewed with the draft questionnaire allowing them to answer freely for each of the items of inquiry. Such answers given for each of the queries were recorded and categorized afterwards to form the five or seven scale Likert options against each query.

Having set the questionnaire with Likert options, the three groups of learners were requested to respond them and their answers were validated with the answers they offered in the interview. The validated questionnaire with Sinhalese translation (of both questions and Likert options) has been executed with 110 engineering undergraduates of University of Moratuwa. The sample for this investigation is selected from the population of 800 new entrants to the Faculty of Engineering as explained below.

The entire intake (800) of the Engineering Faculty undergoes ESL sessions under the Department of Languages in parallel classes. The Department of Languages at the University of Moratuwa considers 35 to 40 students in a class to be the optimum learner population for an ESL class thus the entire batch of students in ESL sessions are in 35 to 40 students' groups in many parallel classes. The sample for the questionnaire administration consisted of three such classes wherein the researcher undertook teaching thus assuring 35 to 38 learners in each from among twenty three such classes who underwent the same material. The sample thus was selected randomly from among mixed ability groups of learners irrespective of their gender, ethnic or demographic concerns.

\section{Data Analysis Process}

Each query in the questionnaire has been provided with descriptive Likert options corresponding to a defined metacognitive scale for the learners to choose from. Such Likert options are indicative of the states of cognitive characteristics possessed by the learners and they are scaled as $-2,-1,0,+1,+2$ range thus aligning within the metacognitive scale. Once the learner opted any of the statuses it adds marks either as positive or negative thus placing the metacognitive sensitivity of the learner in right place of the scale. Score ' 0 ' in the scale reflects the indifference to metacognitive phenomena while scores $(-1),(-2)$ reflect diminishing attention towards metacognitive phenomena. Scores ' 1 ' and ' 2 ' reflect growing adherence towards metacognitive phenomena. This has applied to all the elements of metacognitive taxonomy and the sample's cumulative marks are 
Table 4: Correlation between to-do list with Evaluation of the Plans and amend strategies.

\begin{tabular}{llcc}
\hline Independent variable & Dependent variable & P-correlation & Significance (2-tailed) \\
\hline $\begin{array}{l}\text { I make a 'to do list' includ- } \\
\text { ing the strategies I'm us- }\end{array}$ & $\begin{array}{l}\text { I evaluate my improve- } \\
\text { ment towards achieving }\end{array}$ & $0.353^{* *}$ & 0.000 \\
ing for each sub task & I usually evaluate & & \\
& my strategies and & $0.490^{* *}$ & 0.000 \\
amend/correct them & & \\
$\begin{array}{l}\text { I evaluate my improve- } \\
\text { ment towards achieving } \\
\text { my goals }\end{array}$ & $\begin{array}{l}\text { my strategies and } \\
\text { amend/correct them }\end{array}$ & $0.454^{* *}$ & 0.000 \\
\hline
\end{tabular}

$$
\mathrm{N}=110
$$

Correlation is significant at the 0.01 level (2-tailed).

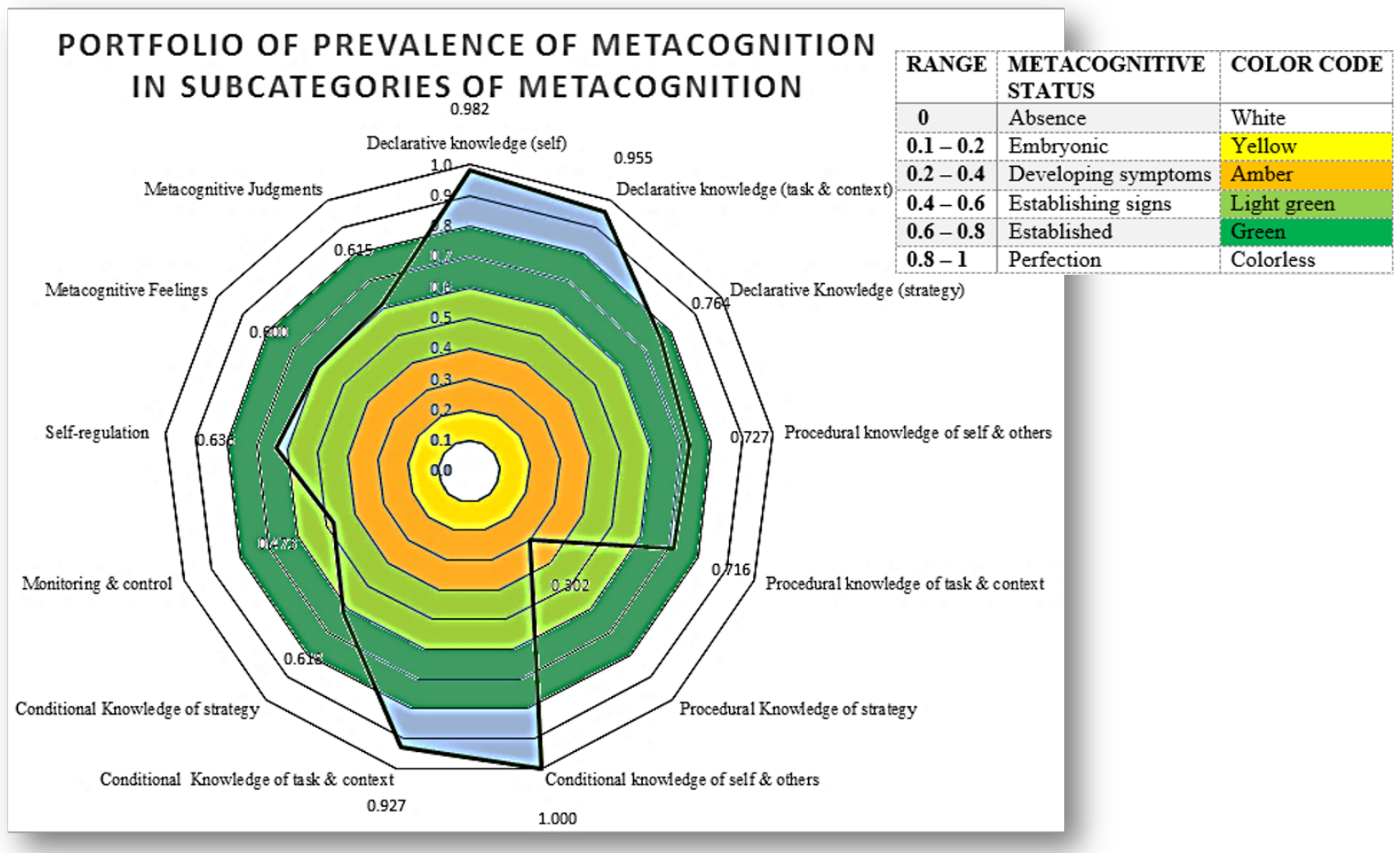

Figure 1: Portfolio of Prevailing Metacognitive Knowledge and Skills

calculated for each component of the metacognition. The portfolio is composed by considering the aggregate of the marks gained by the learner sample. The example query of the questionnaire and the cognitive traits reflective of metacognitive scale illustrated in Table 2 provides the method in a nutshell.

For the analytical clarity and precision, such data are coded corresponding to the metacognitive scale values elaborated in Table 2 assuring the analyzability using Statistical Package for the Social Sciences (SPSS) ver- sion 19.00 which is an up-to-date platform for statistical analysis.

The cumulative means of the sample responses against each query with corresponding aspect of metacognition are stratified in a radar chart thus forming the portfolio of metacognitive strategy in use among learners. 
Table 5: Correlation: knowing constructive causes, being shrewd on how they emerge \& skill to stimulate them.

\begin{tabular}{llcc}
\hline Independent variable & Dependent variable & P-correlation & Significance (2-tailed) \\
\hline $\begin{array}{l}\text { I do know what causes } \\
\text { do constructively effect on } \\
\text { my mission. }\end{array}$ & $\begin{array}{l}\text { I do know how those posi- } \\
\text { tive causes emerge. }\end{array}$ & $0.274^{* *}$ & 0.005 \\
& $\begin{array}{l}\text { I do know how to stimulate } \\
\text { such positive causes. }\end{array}$ & $0.237^{*}$ & 0.016 \\
$\begin{array}{l}\text { I do know how those posi- } \\
\text { tive causes emerge. }\end{array}$ & $\begin{array}{l}\text { I do know how to stimulate } \\
\text { such positive causes. }\end{array}$ & $0.498^{* *}$ & 0.000 \\
\hline
\end{tabular}

\section{$\mathrm{N}=110$}

**Correlation is significant at the 0.01 level (2-tailed).

*Correlation is significant at the 0.05 level (2-tailed).

\section{Results and Discussion}

\section{Portfolio of Cognitive/ Metacognitive characteristics}

The summary of findings of the entire questionnaire survey at a portfolio level is illustrated in the radar graph in Figure 1. The chart indices metacognitive knowledge and skills possessed by the learners in each sub category level of the taxonomy of metacognition. The objective of forming the portfolio of prevalent metacognitive awareness and skills is to identify the existing skills with the learners while detecting the areas that need further emphasis and training through ESL input components. The area covered black line graph with colours indicate the prevalence of metacognitive behaviors as found from the learner responses. Covering the highest contour of the radar graph is the objective of ESL learning mission. The residual lines of the sample statistics and the distance between such residual points to the highest contour of the radar indicate the areas to be considered in ESL input components. In the radar graph, the levels in which metacognitive behaviors prevail are indicated through the rubric given below.

The legend descriptors of the Figure 1 consists colour codes. The white coloured center (0 to 0.1$)$ in the radar graph indicates the total absence of metacognitive knowledge or skills while the territory coloured in yellow (0.1 to 0.2 ) indicates the embryonic signs of metacognitive knowledge and skills awakening. The sample of learners in the study has no record of lagging in or around these areas of poor metacognitive signs.

Amber coloured area leading from 0.2 to 0.4 range indicates developing symptoms of metacognitive skills and knowledge which needs further orchestration to sustain and lead towards the periphery of the radar chart. The least average earned by the sample of learners in the survey lags at 0.302 which specifies the knowledge of strategy possessed by the learners. This subcategory of metacognition being a component of metacognitive knowledge alarms us the need of espousing content in the ESL input targeting the enhancement of such knowledge dimensions of metacognition. The content and the frequency of such material have to be dominating in the ESL input as it remains the least equipped dimension of metacognition.

Establishing signs of metacognition range from 0.4 0.6 and they are marked in light green colour. Monitoring and control subcategory lags within this range with 0.473 score along with metacognitive feelings subcategory rests in the outer border with 0.6 score. Both these subcategories belonged to metacognitive skills of the taxonomy of metacognition. These two subcategories ask for greater attention in the prospective ESL input as they are to be indoctrinated with emphasis in the teaching learning process.

The components of metacognition that has an established status are positioned within scores 0.6 to 0.8 within dark green contours. Most of the subcategories such as: declarative knowledge of strategy, procedural knowledge of self and others, procedural knowledge of task and context, conditional knowledge of strategy belonged to the metacognitive knowledge dimension rest within this positive state of established nature. Selfregulation and metacognitive judgements belonged to the domain of metacognitive skills also rest in this range of established stage of metacognition. In composing the ESL input, these components of established nature are to be induced in introductory and application nature.

Certain subcategories of metacognition, namely, declarative knowledge of self, conditional knowledge of self and others and conditional knowledge of task and context, all belonged to metacognitive knowledge dimension rest in perfection range of the metacognitive indicator coloured in light blue. These aspects of metacognition can be induced in the strategy content of the ESL input upon the demand of communicative activity.

The portfolio of prevalent metacognitive knowledge and skills hence provides the base for determining metacognitive strategy in the ESL input. The portfolio thus serves as the guideline for determiner of the 
dosage and the due level of emphasis relevant to the metacognitive strategy component of ESL input.

\section{Specific Outcomes}

The study beyond its central concerns was able to unveil several implications relevant to ESL context and such are discussed herein. Data has been gathered for the purpose of distinguishing prevalent metacognitive strategy inventory of the learners. Such data of correlative nature allows the study to ascertain certain ground realities relevant to the context of ESL in the research field. Thus a correlative analysis is performed for such data of confident nature for establishing correlations. Pearson correlation coefficient formula is used in analyzing data with the view of discerning any relationship exist between learners' confidence over each skill of the language and their impact on other skills of the language. The correlation can vary from -1 (perfect negative correlation) through 0 (no correlation) to +1 which is a perfect positive correlation. The significance value indicates ( $p$-value) the nature of importance for the validity of the hypothesis. If the value is less than 0.01 the relationship is significant which convinces the fact that there exists a relationship between the two variables (or null hypothesis is rejected).

\section{Learners' planning behavior and the abil- ity for strategy distinguishing}

Correlation statistics are taken between the two variables: I usually plan myself and list out what I should do to achieve my language goals and I can distinguish strategies to achieve my goals of language learning. Table 3 shows how closely the two variables relate to one another.

Despite the relationship between learners' planning and learners' ability for distinguishing strategy being not considerably strong as per Table 3, the data indicates that there exists a correlation between the two. The correlation table figures convince that when the learner plans more his ability to distinguish the strategy is enabled mostly. This nature of relationship is vital for the fact that in metacognitive apprenticeship, a learner who is trained to establish a planning behavior can yield strategy discerning skill in result.

\section{Possession of a to-do list with Evaluation of the Plans and improve strategies}

Correlative statistics of having a 'to do list' and the learner's tendency for amending the strategies and the correlation between evaluating the strategies and the learner's tendency for adjusting the strategies are as follows.

The positive correlation of 0.35 in the Correlation Table 4, is a significant indicator of the relationship which establishes the fact that, having a 'to do list' leads a learner to evaluate strategies towards achieving goals. The strongest correlation exists in the table
0.49 between having a 'to do list' and the propensity of evaluation lead to amend strategies is indeed a finding of grandeur. When a learner possesses a checklist of strategies and targets it leads him to evaluate the learning process, thus enabling the learner to empower decision making for amending the strategies to reach perceived goals. It is evident that the learners' evaluation of strategies also has a strong positive relationship on enabling the learner to amend/alter strategies towards achieving learning goals.

\section{Knowing Constructive Causes, shrewd- ness on emergence of causes and astute for stimulating them}

In the higher levels of metacognitive behavior, a learner encounters the metacognitive feelings that lead to metacognitive experience. A learner with the ability to distinguish constructive causes for his mission of learning do possess the caliber for extending such skill to gain shrewdness on how such causes emerge which can be led further to stimulate such causes. Having hypothesized that these variables possess a relationship, a correlation test is performed. The table (Table 5) of correlation statistics show the possible relationships.

As per the Table 5 statistics, those with significant correlation values establish the hypothesis that there exist a relationship between knowing the constructive causes and the knowledge of how such causes emerge. The correlation established thus is slightly strong since the $\mathrm{P}$ correlation coefficient value being .27. The correlation between knowing the constructive causes and knowing how to stimulate them stands a positive one with a $\mathrm{P}$ correlation coefficient value equivalent to 0.24 .

The most convincing aspect of the relationship is that once the learner knows how positive causes emerge $\mathrm{s} /$ he possesses a reasonable astute for stimulating them. This relationship is evident in 0.49 positive $\mathrm{p}$ correlation value displayed between the two variables.

\section{Knowing negative Causes, shrewdness on emergence of causes and astute for hin- dering them}

A learner with the ability to distinguish negative causes exactly, upon its emerging $\mathrm{s} /$ he can extend that knowledge to hinder/overcome such causes. The nullhypothesis in such is that there exist no-relationship between the variables. The Table 6 of correlation statistics show the results of the correlation test.

The significant correlation values shown in Table 6 , against each correlation test establish the hypothesis that there exist relationship between knowing the negative causes and knowing how such causes emerge. The p correlation 0.29 establishes that it is slightly strong. The correlation between knowing the negative causes and knowing how to overcome them stands a more positive relationship with a $\mathrm{P}$ correlation coefficient value equivalent to 0.32 . The relationship between knowing 
Table 6: Correlation: knowing negative causes, being shrewd on how such causes emerge \& skill to hinder them

\begin{tabular}{llcc}
\hline Independent variable & Dependent variable & P-correlation & Significance (2-tailed) \\
\hline $\begin{array}{l}\text { I do know what causes } \\
\text { do adversely effect on my } \\
\text { mission. }\end{array}$ & $\begin{array}{l}\text { I do know how those ad- } \\
\text { verse causes emerge. }\end{array}$ & $0.0288^{* *}$ & 0.004 \\
& $\begin{array}{l}\text { I do know how to overcome } \\
\text { and control such negative } \\
\text { causes. }\end{array}$ & $0.315^{* *}$ & 0.001 \\
$\begin{array}{l}\text { I do know how to overcome } \\
\text { verse causes emerge. }\end{array}$ & $\begin{array}{l}\text { and control such negative } \\
\text { causes. }\end{array}$ & $0.529^{* *}$ & 0.000 \\
\hline
\end{tabular}

$$
\mathbf{N}=\mathbf{1 1 0}
$$

**Correlation is significant at the 0.01 level (2-tailed).

how negative causes emerge and how to overcome them is very strong owing to the $0.53 \mathrm{P}$ correlation coefficient value. The observation is that once the learner knows how negative causes emerge s/he possesses an assured astute for taking actions to overcome them.

\section{Conclusions}

Findings of the study linger sequestered among other researches in cognitive approaches to language teaching perhaps for its exclusivity in terms of the nature of investigation. The absentia of studies published in the particular domain is thus considered both a limitation of the study as these findings are unable locate within other researches in the focus, and the object as such gap of literature provides the reason for the present study. The study reached the conclusions drawn below from the findings of the study.

The survey data proved that learners are intrinsically aware of almost every level of the metacognitive behaviors and strategies in learning ESL while the witnesses on students' congruity with self-tenable strategies establishes the higher metacognitive sense possessed by the sample. The diagnosis provided witnesses for the prevalence of strategies of highly metacognitive nature among leaners with instances in which learners find themselves capable of metacognitive feelings and judgements with regard to the use of strategies of metacognitive nature.

The mapping of Portfolio of metacognitive traits of the learners serves as a cornerstone guideline for the ESL input planner to determine metacognitive components for the input calibrated for learner cognition.

The correlation analysis establishes that there exists links among planning, monitoring and control behaviors towards enabling metacognitive feelings and judgements. This correlation analysis achieves tenable evidences for the three conclusions arrived. The sample of learners concerned shows the proofs of prevalence of metacognitive strategies within their learner-self. Prevalent metacognitive strategies of learners manifest signs of learners' ability to retain self-tenable strategy. The correlative nature among these strategies being positive admits that a vital relationship exists between the perception of right strategies and learners' use of them.

The portfolio (of prevalent metacognitive knowledge and skills) provides the base for determining metacognitive strategy in the ESL input. The portfolio thus serves as the guideline or determiner of the dosage and the due level of emphasis relevant to the metacognitive strategy component of ESL input. The questionnaire aligned with taxonomy of metacognition proved to be of definite viability to deploy in the investigation of prevailing metacognitive skills among learners which will serve as a tool of ESL needs analysis.

\section{References}

Anderson, N. J. (2003) Metacognitive reading strategies increase L2 performance. The Language Teacher, v.27, pp.20-22.

Bransford, J.D., Brown, A.L., Cocking, R.R. (2000) How people learn: Brain, mind, experience, and school, Washington DC: National Academy Press. DOI:http://dx.doi.org/10.17226/9853

Chamot, A. (2004) Issues in language learning strategy research and teaching. Electronic Journal of Foreign Language Teaching, v.1, pp.14-26. DOI:http://e-flt.nus.edu.sg/v1n12004/chamot.pdf

Chamot, A. U. (1995) 'A Guide for the Teaching of Second Language Listening' In Learning Strategies and Listening Comprehension, D. Mendelsohn, \& J. Rubin (Eds.), San Diego: Dominie Press.

Cronbach, L., Snow, R. (1977) Aptitudes and instructional methods: A handbook for research on interactions. New York: Irvington. DOI:http://dx.doi.org/10.2307/748778 
Cross, D.R., Paris, S.G. (1988) Developmental and instructional analyses of children's metacognition and reading Comprehension. Journal of Educational Psychology, v.80 (2), pp.131-142.

DOI:http://dx.doi.org/10.1037//0022-0663.80.2.131

Doughty, C.J., Long, M.H. (2003) The handbook of second language acquisition. Malden, Ma: Blackwell Publishing.

DOI:https://doi.org/10.1002/9780470756492

Flavell, J. (1976) 'Metacognitive aspects of problem solving' in The Nature of intelligence, Resnick, L.B. (ed.), Hillsdale NJ: Laurence Earlbaum Associates.

Flavell, J., Miller, P., Miller, S. (1993) Cognitive Development. Englewood Cliffs, NJ: Prentice-Hall.

Goh, C. (2008) Metacognitive instruction for second language listening development: Theory, practice and research implications. Regional English Language Centre Journal, v.39 (2), pp.188-213. DOI:https://doi.org/10.1177/0033688208092184

Guilford, J. P. (1967) The nature of human intelligence. New York: McGraw-Hill.

Krashen, S.D. (1982) Principles and practice in second language education, Los Angeles, CA: Pergmon.

Krashen, S.D. (1985) The Input Hypothesis: Issues and Implications. London: Longman.

Langford, G. (1986) 'The Philosophical Basis of Cognition and Metacognition' in Mental Mirrors: Metacognition in Social Knowledge and Communication, Antaki, C., Lewis, C. (Eds.), London: Sage Publications Ltd.

Lightbrown, P.M., Spada, N. (2006) How languages are learned. Oxford, UK: Oxford University Press.

Mohamad Nor, N., Rashid, R.A. (2018) A review of theoretical perspectives on language learning and acquisition. Kasetsart Journal of Social Sciences, v,39(1), pp.161-167.

DOI:https://doi.org/10.1016/j.kjss.2017.12.012

Neitfeld, J.L., Schraw, G. (2002) The effect of knowledge and strategy explanation on monitoring accuracy. Journal of Educational Research, v.95, pp.131142.

DOI:https://doi.org/10.1080/00220670209596583

Oxford, R. (2003) Language learning styles and strategies: An overview. GALA, pp.1-25.

Pickett, J.P. (2000) The American Heritage Dictionary of the English Language, Houghton: Mifflin.

Pintrich, P. R., De Groot, E. V. (1990) Motivational and Self-Regulated Learning Components of Classroom Academic Performance. Journal of Educational Psychology, v.82, pp. 33-40.

DOI:https://doi.org/10.1037/0022-0663.82.1.33
Pintrich, P.R. (2002) The role of metacognitive knowledge in learning, teaching and assessing. Theory in to practice, v.41 (4), pp. 219.

DOI:https://doi.org/10.1207/s15430421tip4104_3

Pressley, M. (2000) 'Development of grounded theories of complex cognitive processing: Exhaustive withinand between study analyses of thinking-aloud data' in Schraw, G., Impara, J. C. (Eds.), Lincoln, NE: Buros Institute of Mental Measurements.

Rubin, J. (1975) What the 'good language learner' can teach us. TESOL Quarterly, v.9, pp. 41-51. DOI: https://doi.org/10.2307/3586011

Rubin, J. (1987) 'Learner strategies: theoretical assumptions, research history and typology' in Learner Strategies in Language Learning, Wenden, A. \& Rubin, J. (Eds.), Hemel Hempstead: Prentice Hall International.

Saville-Toike, M. (2012) Introducing second language acquisition, Cambridge, UK: Cambridge University Press.

DOI:https://doi.org/10.1017/cbo9780511888830

Schraw, G. (1998) Promoting general metacognitive awareness. Instructional Science, v.26, pp.1-2.

Schraw, G. (2001) 'Promoting General metacognitive awareness' in Metacognition in Learning and Instruction: Theory, Research and Practice, Hartman, H.J. (Ed.), Dordrecht: Netherlands: Kluwer Academic Publishers.

Schraw, G., Crippen, K.J., Hartley, K. (2006) Promoting Self-regulation in Science education: Metacognition as part of a broader perspective on learning. Research in Science Education, v.36, pp.111-139. DOI:https://doi.org/10.1007/s11165-005-3917-8

Tanner, K.D. (2012) Promoting student metacognition. CBELife Sciences Education, v.11, pp.113-120. DOI:https://doi.org/10.1187/cbe.12-03-0033

Tarricone, P. (2011) The Taxonomy of Metacognition. New York: Psychology Press.

Thiede, K. W., Anderson, M. C.M., \& Therriault, D. (2003) Accuracy of metacognitive monitoring affects learning of texts. Journal of Educational Psychology, v.95, pp.66-73.

DOI:https://doi.org/10.1037/0022-0663.95.1.66

Witkin, H.A. (1949) The nature and importance of individual differences in perception. Journal of Personality, v.18, pp. 145-70.

DOI:https://doi.org/10.1111/j.1467-

6494.1949.tb01237.x

Witkin, H.A. (1978) Cognitive styles in personal and cultural adaptation. Worcester, MA: Clark University Press. 